\title{
LESSON PLANNING AND TEACHING FINE ART WITH IMPLEMENTATION OF DIGITAL STYLUS
}

\author{
Vanja Kolar Ivačič \\ Primary school Bistrica ob Sotli, Slovenia
}

\begin{abstract}
Creativity is closely linked to $21^{\text {st }}$ century competencies. For students in secondary education, it is important to maintain and encourage creativity as part of fine arts classes. This can be achieved through meaningful integration of information and communication technology, as this allows students to express themselves in a more engaging and in-depth way. To help empower class teachers, this research presents a successful example of good practice. Courses are planned in several stages, starting from goals of the subject in relation to digital competencies. The app for the tablet and the digital pen is selected according to the criteria of quality, simplicity of use and relevance. Technology is included in the lessons with the goal to achieve a significant upgrade of the learning experience. Students evaluate their artistic expression as positive and successful. With this activity, students develop their creative and artistic expression abilities to the greatest extent. Their graphic products meet the art task and are aesthetically perfective for their age. The expressive elements within the computer graphics are originally rhythmically arranged.
\end{abstract}

Keywords: digital pen, example of good teaching, fine arts, innovative pedagogy, lesson planning

\section{Introduction}

"A wave of innovation is being stimulated by the information technology (it) revolution that promises to revitalise our schools" (Aberšek \& Kordigel Aberšek, 2010, pp. 8). The use of modern technology in teaching $2^{\text {nd }}$ educational period is binding in the curriculum for fine arts, even though the recommendations limit it to transmission, keeping and organizing of study material, searching for information, and maintaining new forms of socialization and fine arts communication (Kocjančič et al., 2011). However, the curriculum commits to use the information and communication technology (hereinafter ICT) in artistic expression and even recommends it. Students get educated for successful future and competitiveness in the labour market. The need to employ creative people in all fields is growing, including fine artists who are proficient in the use of digital environments. Since developing and preservation of creativity are closely connected to competence of $21^{\text {st }}$ century (Inovativna šola, 2019), it is hard to imagine a successful future of the students without it. Although creating with concrete art materials and classical tools is extremely important for the students in the $2^{\text {nd }}$ educational period, the inclusion of ICT can have a great impact on the development of creativity. It encourages student motivation, commitment and activity, as modern devices are increasingly becoming part of children's everyday lives.

There may appear some reservations and difficulties in introducing technology into art subjects, especially in empowering classroom teachers to plan and implement innovative approaches. According to Breznik (2019), the examples of good practice present important motivational elements in introduction of digital technology in the learning process, while even in this way teachers get ideas and procedural knowledge, which they later on adapt to their learning environment. An example of an innovative approach from planning to implementation is presented below. $4^{\text {th }}$ grade primary school students successfully developed individual artistic expression using tablets and digital pens. 


\section{Planning}

A set of two lessons was planned according to the model of a pedagogy wheel (Karrington, 2019). The focus was on choosing appropriate methods, forms of work and aims, and on the main question of how to motivate students. The plan was gradualness of activities according to Bloom's taxonomy and to determine the appropriate educational technology. The reasonability of usage was checked according to SAMR model (Substitution, Augmentation, Modification, Redefenition) (Puentedura, 2016). With the help of this particular model it was possible to evaluate the level of didactic use of ICT (Jedrinivić et al., 2018) regarding four levels: replacement (only the replacement of previously used teaching aids and ICT does not bring new functionalities), upgrade (enabling additional functionalities to stimulate cognitive processes), transformation (introduction of new functionalities to stimulate higher cognitive processes), redefinition (possibility to plan activities that would not otherwise be possible).

The research focuses on the question of how the learning experience influences the students to become successful. Since they are able to freely test various options and correct errors without negative consequences when painting with an interactive tool, their final product is likely to be expressively and aesthetically more perfect. They are also able to develop their artistic expression unencumbered.

In accordance with the curriculum in Slovenia (Kocjančič et al., 2011) and recommendations for the good use of ICT devices in teaching, which were created within the project Innovative learning environments supported by ICT (Breznik, 2019), the following goals were pursued:

- the student, in accordance with their abilities, develops creative artistic expression with the support of an ICT tool by aesthetically and perfectly designing a graphic product based on sampling;

- the student develops a sense of rhythmic arrangement of shapes on the surface;

- the student gains the ability to constructively and critically assess their achievements, the achievements of peers and to learn from experience (including mistakes).

Different activities were planned gradually according to Bloom's taxonomy. Memorization included visualizing spring flowers and animals, then rhythmic movement and musical performance of uniform patterns. Students' understanding was tested with conversation about their peer's art products. The students used their knowledge of the arrangement of shapes and qualities of a finished art product to jointly set performance criteria. They created computer graphics, analysed their work, evaluated their classmates' work, highlighted successes, and focused on improvements.

The school where the research was carried out uses sixth-generation iPads with digital pens, therefore the Tayasui Sketches School app was selected (Tayasui, 2018). The app is recommended (Apple inc., 2019), while it is tailored to younger children. Its usage is simple, since it has only a few very effective tools for creating. In this way, students are able to test the effects quicker and choose the most appropriate ones for expression. More possibilities of use and fast switching between them make it easier for students to express their ideas, use imagination and develop creativity. Even if the effect does not meet 
expectations, it is possible to take a step back without consequences. This app works best with the Apple pencil, because it responds to pressure, inclination, and touch speed. It is also possible to use one of the other digital pens. This brings the user even closer to the effects of creating with pencils, crayons, or brushes.

According to the SAMR model (Puentedura, 2016), the implementation of such lessons belongs to the level of change. The art task could be done without ICT and similar results could still be obtained, yet this would not be graphics, but a unique design on the surface, which would take a lot of time. Shapes would have to be printed, cut, pasted, and combined with various art aids. The app enables one to take a step back, undo the last change, delete it, thus allowing students to learn from mistakes. They can correct them without consequences which motivates the development of their artistic expression. For lasting effects, elements of formative monitoring were also included in the lessons (Novak, 2018). The students participated in determining the performance criteria and self-evaluated their work according to them. The work was completed with peer evaluation in threes. The competence of creative expression and the competence of inducting and reproducing digital content at the $4^{\text {th }}$ and $5^{\text {th }}$ level of difficulty were primarily developed in students (Carretero et al., 2017).

\section{Conducting Lessons}

An hour before the planned performance, the students became acquainted with the app and the pen. The process was demonstrated by connecting the teacher's iPad to a smart screen and explaining the basic design procedures. There was emphasis on the mode of choosing a smaller motif, copying with two fingers, and shifting and rotating with one. They were reminded about hand hygiene before and after using a tablet and pen, and also about the caution of handling with devices. After that, the students independently tested and learned about the environment. The first thing that had to be repeated was knowledge about rhythm in fine art and about the even and uneven repetition of forms in a work of art. Such works of art are usually patterns and act decoratively, ornamentally. This was followed by a thematic connection with mathematics - patterns and symmetry - and Slovene - a dramatic text by F. Puntar: Vzorček. Next step was rhythmic game - movement patterns around the class. In this way, patterns and rhythm could be connected with music and sports, and students were active.

However, unevenly distributed forms can often be encountered in art. Students were shown a short instructive film on how Henri Matisse created his cutouts. They observed how the artist helped himself to rearrange the shapes and how long it took him the arrangement of shapes on the artwork displays and arranged them into evenly spaced and unevenly spaced. Next, they listed examples of even distribution in the surroundings and nature. Spring floral patterns were reached soon; they are especially suitable for greeting cards. The performance took place before Mother's Day and the art task was to make greeting cards for mothers or grandmothers. This was followed by a conversation about greeting cards and the purpose of making them. The concept of graphic design was repeated. It is usually defined as an art form which deals with the design of graphic products intended for printing in larger editions. Students listed examples of its use: designing posters, labels, magazines, stickers, greeting cards, invitations, etc. They were given an art task to create computer graphics with a tablet and a digital pen in order to make a greeting card for their mothers and grandmothers. 
One example of a linear design and one example of a circular design were inspected on their peers' products. The performance criteria were designed and written down together.

"I will be successful when:

- $\quad$ I create smaller spring motifs;

- I copy, paste, enlarge, reduce or rotate the motifs and distribute them rhythmically evenly on the artistic background;

- I I use coordinated colours, also for the background;

- I I $\quad$ am precise and thorough (I know about the possibility of stepping back and deleting);

- $\quad$ I include innovative ideas of patterning;

- $\quad$ The art surface is filled."

Each student then designed an art product for the greeting card on their device in accordance with the demonstration. They were encouraged to carefully select and copy the elements and incorporate their own, imaginative ideas. Feedback and guidance were provided if needed. The teacher assisted in the procedures of storing the finished product and exporting it in a format suitable for printing. Students completed a self-assessment sheet on the spot. A guided conversation followed, where students who wished presented their ideas and shared their experiences. Various artistic solutions and imaginative details were observed on the products. This was followed by peer evaluation in threes. The student wrote down on the peer evaluation form what his classmates had told him. The graphics were printed the following week and the students pasted them on one-color cardboard in order to make a greeting card. Since their product as a graphic is durable, they already came up with ideas of where else they could use it (wrapping paper for notebooks, labels, invitations, posters, etc.).

\section{Figure 1}

Student's Graphics in Linear Design

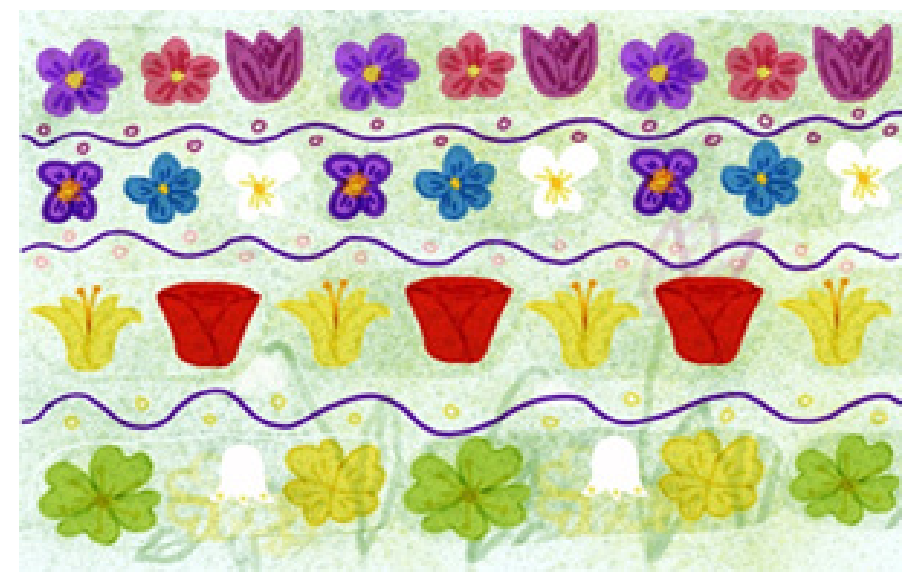




\section{Figure 2}

Student's Graphics in a Circular Design

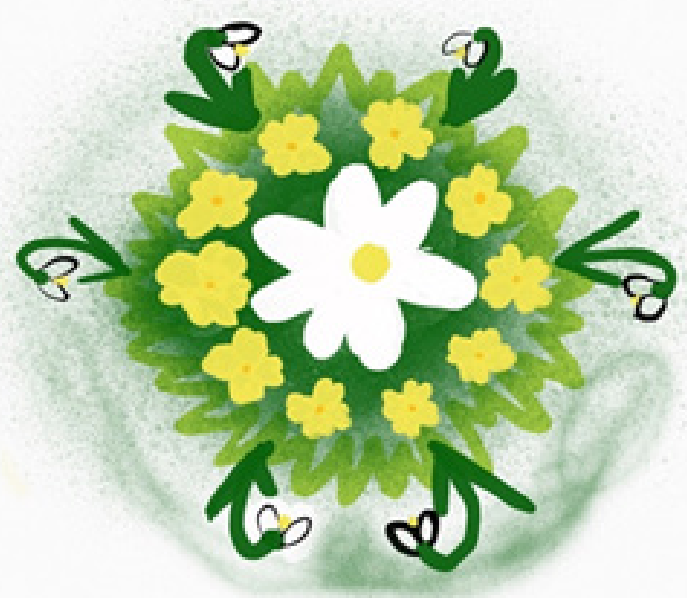

\section{Conclusions}

The presented example of the introduction of digital technology in fine arts class in the $4^{\text {th }}$ grade was successful in terms of effects. The students were extremely motivated to work. In the classroom, twenty students so enthusiastically created in silence that they did not want to take a break. It was possible to see the enthusiasm about the product and two even stated they did not know they could create something so beautiful. The previously co-created criteria provided support during creation. They highly praised the possibility of feedback during the implementation, both from the teacher as well as their peers. Furthermore, due to working with digital tools, they were able to respond immediately and repair and upgrade the product without consequences. Many wanted to upgrade their product even after the end of peer evaluation, but this was not possible, which is regrettable. If students had their own devices, they could complete the product at home.

The fine art lesson was a satisfactory experience which helped to achieve all the previously set aims, which does usually not happen.

If the teacher does not have the option of using Apple's digital pen, they may use another digital pen (or attachment), which may be of lower quality but more affordable. Students will probably not be able to be as much precise, and the ability to respond to pressure will also be impoverished.

After two months, another two hours of fine arts classes were carried out in a similar way. Only the main theme (summer) was changed, and the collage overlay technique was strongly highlighted. There was a noticeable progress in the implementation as well as in providing feedback. The presented approach to planning and implementation is transferable to other areas of teaching. 


\section{References}

Aberšek, B., \& Kordigel Aberšek, M. (2010). Information communication technology and e-learning contra teacher. Problems of Education in the 21st Century, 24, 8-18. http://www.scientiasocialis.1t/pec/node/434

Breznik, I. (2019). Priporočilo za razvoj primerov obetavne rabe v projektu Inovativna učna okolja podprta z IKT [Recommendation for the development of promising use cases in the project Innovative learning environments supported by ICT]. https://drive.google.com/file/d/1 VykA qiCIp05WU8tuQividvFQpS2jq8N_/view

Carretero, S., Vuoricari, R., \& Punie, Y. (2017). Dig.Comp. 2.1. Okvir digitalnih kompetenc za državljane. Osem ravni doseganja kompetenc in primeri rabe [Dig.Comp. 2.1. Digital Competence Framework for Citizens. Eight levels of competence achievement and use cases]. Zavod RS za šolstvo. https://www.zrss.si/pdf/digcomp-2-1-okvir-digitalnih-kompetenc.pdf

Carrington, A. (2018). The Padagogy Wheel. Slovenian. [poster]. https://designingoutcomes.com/ pwslv5/

Apple inc. (2019). Everyone can create teacher guide for early learners. Apple Education. https://www.apple.com/education/everyone-can-create/

Kocjančič, N. F., Karim, S., Kosec, M., Opačak, Ž., Prevodnik, M., Rojc, J. ... Selan, J. (2011). Učni načrt. Program osnovna šola. Likovna vzgoja [Curriculum. Elementary school program. Art Education.]. Ministrstvo za šolstvo in šport, Zavod RS za šolstvo. https://www.gov.si/assets/ ministrstva/MIZS/Dokumenti/Osnovna-sola/Ucni-nacrti/obvezni/UN_likovna_vzgoja.pdf

Matisse, H. (2014). The Cut-Outs. [video]. https://www.youtube.com/watch? ${ }^{2}=r L g S d$ d 8 ka0Gs\&fea ture=youtu.be

Inovativna šola. (2019). Kompetence 21. Stoletja [Competences of the 21st Century]. https://www.inovativna-sola.si/

Istyle. Apple pencil. (b.d.). https://istyle.si/apple-pencil.html

Jedrinović, S., Cerar, Š., Zapušek, M., Kristl, N., Papić, M., Žurbi, R., Danko, M., Keržič, D., Dečman, M., Radovan, M., Rugelj, J., Bešter, J., \& Savec, V. F. (2018). Strokovna izhodišča za didaktično uporabo IKT na 9 študijskih področjih [Professional starting points for the didactic use of ICT in 9 study areas]. http://naslokar.fmf.uni-lj.si/FMF/sidu. pdf\#page $=83 \&$ zoom $=100,92,425$

Novak, L. (2018). Formativno spremljanje na razredni stopnji [Formative monitoring at the grade level]. Manual. Zavod Republike Slovenije za šolstvo.

Puentedura, R. R. (2015). SAMR. A brief introduction. http://hippasus.com/rrpweblog/ archives/2015/10/SAMR_ABriefIntro.pdf

Tayasui Sketches School. [application] (2018). https://apps.apple.com/us/app/tayasui-sketchesschool/id1354087061

Received 12 May 2021; Accepted 18 June 2021

Cite as: Kolar Ivačič, V. (2021). Lesson planning and teaching fine art with implementation of digital stylus. Gamtamokslinis ugdymas / Natural Science Education, 18(1), 7-12. https://doi.org/10.48127/gu-nse/21.18.07

\section{\begin{tabular}{ll}
\hline & Vanja Kolar Ivačič
\end{tabular}}

Teacher 4th grade, Primary School Bistrica ob Sotli, 63a, 3254 Bistrica ob Sotli, Slovenia.

E-mail:vanjak@osbistricaobsotli.si

Website: https://www.osbistricaobsotli.si 